\title{
R202Q gen değişikliğinin ailesel Akdeniz ateşi kliniği üzerine etkisi: tek merkez deneyimi
}

\author{
The effects of R202Q genotype on the clinical features of familial Mediterranean fever: \\ single center experience
}

\author{
Serkan Türkuçar, Hatice Adıgüzel Dundar, Ceren Yılmaz, Erbil Ünsal
}

Gönderilme tarihi:23.02.2021

Kabul tarihi:15.04.2021

Öz

Amaç: Ailesel Akdeniz ateşinin kliniğinde görülen tekrarlayan febril poliserozit atakları, MEFV genindeki mutasyonlara bağlı kontrolsüz interlökin 1- $\beta$ salınımından kaynaklanmaktadır ve hastalığın seyri mutasyonlara göre değişkenlik gösterebilmektedir. Bu çalışmada R202Q gen değişiminin klinik ve laboratuvar bulguları üzerindeki etkisinin değerlendirmesi amaçlanmıştır.

Gereç ve yöntem: 122 pediatrik AAA hastasının demografik, klinik ve laboratuvar verileri kıyaslanmıştır. Hastalar MEFV mutasyonlarına göre R202Q değişimini heterozigot, homozigot, ekzon-10 mutasyonları ile bileşik heterozigot bulunduranlar ve sadece ekzon-10 mutasyonu bulunduranlar olarak gruplandırılarak karşılaştırılmıştır.

Bulgular: Demografik, antropometrik, klinik ve laboratuvar bulgular açısından değerlendirildiğinde, gruplar arasında herhangi bir istatistiksel anlamlı fark saptanmamıştır.

Sonuç: R202Q gen değişikliğine sahip hastalarda da ekzon 10 mutasyonlu hastalar gibi tipik AAA klinik bulguları gözlenebilmektedir. Ailesel Akdeniz ateşi, genotipik ve fenotipik özelliklerinin birlikte değerlendirilmesi gereken bir hastalıktır.

Anahtar kelimeler: MEFV mutasyonu, ekzon-2, ailesel Akdeniz ateşi, R202Q.

Türkuçar S, Adıgüzel Dundar H, Yılmaz C, Ünsal E. R202Q gen değişikliğinin ailesel Akdeniz ateşi kliniği üzerine etkisi: tek merkez deneyimi. Pam Tıp Derg 2021;14:870-877.

\begin{abstract}
Purpose: Recurrent febrile polyserositis attacks of familial Mediterranean fever are caused by uncontrolled interleukin 1- $\beta$ release due to mutations in the MEFV gene and the course of the disease may vary according to mutations. In this study, it was aimed to evaluate the effect of R202Q genotypes on clinical and laboratory findings.

Materials and methods: Demographic, clinical and laboratory data of 122 pediatric FMF patients were compared. The patients were grouped according to the MEFV mutations as heterozygous and homozygous $\mathrm{R} 202 \mathrm{Q}$, compound heterozygous with exon-10 mutations and R202Q genotypes, and those with only exon-10 mutations compared.

Results: In terms of demographic, anthropometric, clinical and laboratory findings, there was no statistically significant difference between the groups.

Conclusion: Typical clinical findings can be observed in patients with R202Q gene alterations, as in patients with exon 10 mutations. Familial Mediterranean fever is a disease that should be evaluated together with its genotypic and phenotypic characteristics.
\end{abstract}

Key words: MEFV mutations, exon-2, familial Mediterranean fever, R202Q.

Turkucar S, Adiguzel Dundar H, Yilmaz C, Unsal E. The effects of R202Q genotype on the clinical features of familial Mediterranean fever: single center experience. Pam Med J 2021;14:870-877.

\footnotetext{
Serkan Türkuçar, Uzm. Dr. Dokuz Eylül Üniversitesi Tıp Fakültesi, Çocuk Sağlığı ve Hastalıkları Anabilim Dalı, Çocuk Romatolojisi Bilim Dalı, İzmir, Türkiye, e-posta: serkan_turkucar@hotmail.com (https://orcid.org/0000-0003-4700-1361) (Sorumlu Yazar)

Hatice Adıgüzel Dundar, Uzm. Dr. Dokuz Eylül Üniversitesi Tıp Fakültesi, Çocuk Sağlığı ve Hastalıkları Anabilim Dalı, Çocuk Romatolojisi Bilim Dalı, İzmir, Türkiye, e-posta: haticeadiguzel@hotmail.com (https://orcid.org/0000-0003-1469-9900)

Ceren Yılmaz, Uzm. Dr. Dokuz Eylül Üniversitesi Tıp Fakültesi, Çocuk Sağlığı ve Hastalıkları Anabilim Dalı, Çocuk Genetik Bilim Dalı, İzmir, Türkiye, e-posta: yilmaz.ceren@deu.edu.tr (https://orcid.org/0000-0002-0853-3253)

Erbil Ünsal, Prof. Dr. Dokuz Eylül Üniversitesi Tıp Fakültesi, Çocuk Sağlığı ve Hastalıkları Anabilim Dalı, Çocuk Romatolojisi Bilim Dalı, İzmir, Türkiye, e-posta: erbil.unsal@deu.edu.tr (https://orcid.org/0000-0002-8800-0800)
} 


\section{Giriş}

Tek gen geçişli herediter otoinflamatuvar hastalıkların en sık alt tipi olan ailesel Akdeniz ateşi (AAA), ülkemiz başta olmak üzere Doğu Akdeniz Bölgesi'nden köken alan toplumlarda oldukça sık görülür [1]. Kliniğinde kendini sınırlandıran ve tekrarlayan ataklar halinde gelen ateşin eşlik ettiği karın, göğüs ya da eklem ağrısı şikayetleri görülür. Bu ataklara neden olan abartılı inflamasyonun altında interlökin 1- $\beta$ (IL 1- $\beta$ ) nın kontrolsüz salgılanması yatar [2].

Hastalığa neden olan genetik mutasyon 1997 yılında 16. kromozomun kısa kolunda bulunan MEFV (MEditerranean FeVer) geninde tanımlanmıştır [3, 4]. Bu gen pro-IL 1- $\beta$ nın, aktif olan formuna dönüşme basamaklarında kısıtlayıcı rol oynayan pyrin adlı proteini kodlar. Günümüze kadar MEFV geninde ekzon 2, 3, 5 ve 10 da olmak üzere 379 farklı değişiklik bildirilmiştir [5]. Bu genetik değişikliklerin dağılımı ve çeşitliliği toplumlara göre farklılık gösterebilirken; ülkemizde en sık rastlananlar ekzon 10 da bulunan M694V, M680I ve V726A mutasyonları ile ekzon 2 de bulunan R202Q ve $E 148 Q$ değişiklikleridir [6-8]. Onuncu ekzon mutasyonları ile hastalık belirtileri ve ciddiyeti arasında ilişkiler literatürde iyi tanımlanmış olmakla birlikte, R202Q gibi sık rastlanan değişikliklerin hastalık üzerine etkisi net bilinmemektedir [9-11]. İkinci ekzonun 605. pozisyondaki Guanin yerine Adenin geçmesi ile oluşan (c.605G>A) R202Q gen değişimi (p.Arg202Gln), ilk olarak 1998 de Bernot ve ark. [12] tarafından polimorfizmolarak tanımlanmıştır. Fakat daha sonraki araştırmalarda bu polimorfizmin sağlıklı popülasyonla karşılaştırıldığında AAA hastalarında daha sık gözlenmesi, hastalık yapıcı bir genetik değişiklik olabileceğini düşündürmüştür [13-15]. Bununla birlikte, günümüzde infevers genetik veri tabanında R202Q'nun M694V mutasyonu ile bağlantısının genetik dengesizliğe yol açabileceği bildirilmektedir [16].

Bu çalışmanın amacı, toplumumuzda sıklıkla görülmekle birlikte, hastalığın seyri üzerindeki etkisi net tanımlanmamış olan R202Q değişimini, çocuk AAA hastalarımızın klinik ve laboratuvar bulguları üzerinden değerlendirmektir.

\section{Gereç ve yöntem}

Çalışma için, Dokuz Eylül Üniversitesi Girişimsel Olmayan Etik Kurulu'ndan etik onayı alınmıştır.

\section{Hastalar}

Üçüncü Basamak Sağlık Merkezimizin Çocuk Romatoloji Bilim Dalı'nda 1990 ve 2020 yılları arasında AAA tanısı ile takip edilen 122 pediatrik yaş grubu hastanın kayıtları geriye dönük olarak incelenmiştir. 6-72 saat arası süren tipik ateş, karın ağrısı, göğüs ağrısı ve artrit ataklarına ek olarak AAA aile öyküsünden oluşan Ankara klinik tanı kriterlerinden en az ikisini karşılayanlar tanı alarak çalışmaya dahil edilmiştir [17]. Çalışmaya dâhil edilen hastalar, daha önceden çalışılmış MEFV gen analizi değerlendirmesinde R202Q değişimi bulundurmalarına göre gruplara ayrılmıştır. Toplam 1100 pediatrik AAA hasta dosyasının içinden 20 adet R202Q heterozigot, 20 adet R202Q homozigot, 52 adet R202Q ve ekzon-10 mutasyonunu birlikte bulunduran ve 30 adet sadece ekzon 10 mutasyonu bulunduran olmak üzere değerlendirilmiştir. Toplam 122 hasta dosyası, her bir grup içinden rastgele seçilerek çalışmaya alınmıştır.

Hastalar MEFV genlerindeki ekzon 10 mutasyonları ve R202Q gen değişimlerine göre, R202Q heterozigot hastalar: grup 1; R202Q homozigot hastalar: grup 2, R202Q ve ekzon 10 mutasyonlarının birlikte bulunduğu hastalar: grup 3 ve ekzon 10 mutasyonu olup R202Q değişimi bulunmayanlar ise: grup 4 olarak sınıflandırılmıştır.

\section{Klinik ve demografik veriler}

Tüm hastaların dosyalarından ve elektronik veri kayıt sistemindeki verilerden elde edilen yaş, cinsiyet, son ziyaretlerindeki vücut ağrılığı ve boy, ilk atak yaşı, kolşisin başlanma zamanı, tanıda gecikme süresi ve ataklardaki şikâyetleri gibi demografik ve klinik bilgileri not edilmiştir. Vücut ağırlığı ve boy değerlerinin yaşa uygun şekilde Neyzi ve ark. [18] verilerine göre persentilleri hesaplanmıştır. Ayrıca tüm hastaların ataklar arasında eklem şikâyeti olup olmadığı, tekrarlayan tonsillit ve apendektomi öyküleri, Pras ve ark.'nın [19] skorlama sistemine göre hesaplanmış AAA ciddiyet skorları ve kullanılan günlük kolşisin dozları kaydedilmiştir. Elektronik hasta kayıt sisteminden elde edilen veriler üzerinden, tüm hastaların atak arası dönemde bakılan en son hemogram parametreleri [hemoglobin $(\mathrm{Hb})$, beyaz küre $(\mathrm{BK})$ ve platelet (PIt) sayıları ile nötrofil/lenfosit oranları (NLR)] kaydedilmiştir. Ayrıca, eş zamanlı bakılan akut faz yanıtları [eritrosit sedimantasyon hızı (ESH) 
ve C-reaktif protein düzeyleri (CRP)], karaciğer ve böbrek fonksiyon testleri [kreatinin $(\mathrm{Cr})$ ve alanin aminotransferaz (ALT)] ve idrarda protein atıımları da not edilmiştir.

\section{Genetik analiz}

AileselAkdeniz ateşi klinik tanısı ile çalışmaya dâhil ettiğimiz 122 hastanın tamamının MEFV gen analiz sonuçları değerlendirmeye alınmıştır. Genetik analizlerin tümü, periferik kandan elde edilen DNA örneklerini Real Time Polimeraz Zincir Reaksiyon (RT-) PCR yöntemiyle, Cobas z480 RT-PCR (Roche, Almanya) cihazı ve LightSNIP Assay (TIB Molbiol, Almanya) kiti ile değerlendirilerek yapılan analizlerdir. Mevcut yöntemle, AAA ile ilişkili olarak değerlendirilenden en sık 9 mutasyon (E148Q, R202Q, M680I, M694V, M694I, K695R, V726A, $\mathrm{R} 761 \mathrm{H}$ ve A744S) kaydedilmiştir.

\section{İstatistiksel değerlendirme}

İstatistiksel analiz SPSS 22 yazılımı kullanılarak yapılmış olup, değerlerin homojen dağılıp dağılmadığı Kolmogorov-Smirnov testi ile incelenmiştir. Homojen dağılmış değerler ortalama \pm standart sapma olarak belirtilirken, heterojen dağılmış değerler medyan ve yüzde 25 ve 75 değerleri ile belirtilmiştir. Gruplar arasındaki kategorik farklılıkları tanımlamak için Ki-Kare testi kullanılmıştır. Parametrik değerleri karşılaştırmak için bağımsız örneklem-T testi, parametrik olmayan değerler için ise MannWhitney $U$ testi kullanılmıştır. $P<0,05$ istatistiksel olarak anlamlı kabul edilmiştir.

\section{Bulgular}

Çalışmaya dâhil ettiğimiz 122 hastanın 60'। kIz $(\% 49,2), 62$ 'si erkek $(\% 50,8)$ iken; ortalama yaşları 12,25 (9,75-13,45) yıldı. Hastaların ortanca ilk atak yaşı 4,5 $(2,5-7,5)$ yıl, ortanca kolşisin başlama yaşı 6 (4-10) yıl ve ortalama tanıda gecikme süreleri $12(6-24)$ ay olarak hesaplanmıştır.

Demografik veriler açısından bakıldığında hastaların hiçbirinde gelişim geriliği saptanmazken; ortanca vücut ağırlık persentilleri $\% 56,5(28,2-88,2)$ ve boy persentilleri $\% 75$ (3989) olarak hesaplanmıştır.

Atakların en sık semptomu olan ateş hastaların 104'ünde $(\% 85,2)$ görülürken, takiben 93 hastada $(\% 76,2)$ karın ağrısı, 50 hastada (\%41) artralji, 23 hastada $(\% 18,9)$ artrit ve yalnızca 8 hastada $(\% 6,6)$ göğüs ağrısı belirtilmiştir. Hastaların \%28,7'sinde $(n=35)$ is ataklar arasında artralji ve miyalji gibi kas iskelet şikâyetleri bildirilirken, ortalama günlük kullanılan kolşisin dozu 1,0 mg olarak saptanmıştır. Ayrıca hastaların tüm laboratuvar verileri Tablo 1'de verilmiştir. Hastaların taşıdıkları MEFV gen değişiklikleri Tablo 2'de detaylı olarak belirtilmişitr.

Demografik, antropometrik, klinik ve laboratuvar bulgular açısından değerlendirildiğinde, $M E F V$ genlerine göre oluşturulan gruplar arasında herhangi bir istatistiksel anlamlı fark saptanmadı, C-reaktif protein değeri üçüncü grupta diğerlerine göre yüksek saptansa da normal sınırlar içinde $(0,5-5$ $\mathrm{mg} / \mathrm{L}$ ) olduğundan anlamlı kabul edilmedi (Tablo 3).

\section{Tartışma}

Ailesel Akdeniz ateşi, MEFV genindeki çok sayıdaki genetik değişikliğin patogenezde rol alabileceği ve farklı genotipik özelliklerin farklı klinik bulgulara yol açabileceği bir hastalıktır. $\mathrm{Bu}$ çalışmamızda, klinik üzerindeki etkisi tartışmalı olan $\mathrm{R} 202 \mathrm{Q}$ gen değişikliğinin $\mathrm{AAA}$ belirtilerine neden olabildiğini; hatta ekzon 10 mutasyonlarıyla kıyaslandığında atak belirtileri, hastalık ciddiyet skorları, atak arası inflamasyon parametreleri ve tedavi dozu gereksinimleri açısından benzer özelliklere sahip olduğu saptanmıştır.

İlksaptandığıdönemlerdegenetikpolimorfizm olarak tanımlanan R202Q değişikliğinin önemi ile ilgili bildirilen çalışmalarda birbiriyle çelişen bilgiler raporlanmıştır. Ritis ve ark. [13], 26 AAA'lı Yunan hastanın 4'ünde homozigot R202Q değişikliği saptarken, 60 sağlıklı kontrolün hiçbirinde R202Q saptamamışlar ve bu genetik değişikliğin bir mutasyon olabileceğini öne sürmüşlerdir. Ülkemizden Öztürk ve ark.'nın [14] bildirdiği bir çalışmada ise, hasta ve sağlıklı kontrol gruplarında benzer oranda heterozigot R202Q değişikliği saptanmasına rağmen, homozigot değişikliğin sağlıklı grupta daha az olduğu raporlanmıştır. Mevcut sonuçlarla heterozigot değişikliklerin polimorfizm, homozigot değişikliklerin ise en azından bazı hastalarda klinik ile ilişkili olduğu iddia edilmiştir. Benzer şekilde Yiğit ve ark.'ları [15], R202Q heterozigot değişiminin AAA ve sağlıklı gruplarda benzer oranda olduğunu, 
Tablo 1. Hastaların demografik, klinik ve laboratuvar verileri $(n=122)$

\begin{tabular}{|c|c|}
\hline Cinsiyet (kız/erkek) & $60 / 62$ \\
\hline Yaş (yıl) & $8,4(6,7-11,5)$ \\
\hline İlk atak yaşı (yıl) & $4,5(2,5-7,5)$ \\
\hline Tedavi başlama yaşı (yıl) & $6(4-10)$ \\
\hline Tanıda gecikme süresi (ay) & $12(6-24)$ \\
\hline Ailede AAA öyküsü ( $1^{\circ}$ ve $2^{\circ}$ akrabalarda) & $49(\% 40,2)$ \\
\hline Akraba evliliği öyküsü ( $1^{\circ}$ ve $2^{\circ}$ akrabalık) & $7(\% 5,7)$ \\
\hline VA $(\mathrm{kg})$ & $25,5(19,4-46,3)$ \\
\hline Boy $(\mathrm{cm})$ & $128,5(111-153)$ \\
\hline VA (persentil) (\%) & $56,5(28,2-88,2)$ \\
\hline Boy (persentil) (\%) & $75(39-89)$ \\
\hline \multicolumn{2}{|l|}{ Atak belirtileri } \\
\hline - Ateş & $104(\% 85,2)$ \\
\hline - Karın ağrısı & $93(\% 76,2)$ \\
\hline - $\quad$ Artrit & $23(\% 18,9)$ \\
\hline - $\quad$ Artralji & $50(\% 41)$ \\
\hline - Göğüs ağrısı & $8(\% 6,6)$ \\
\hline Atak arası kas iskelet şikâyetleri & $35(\% 28,7)$ \\
\hline Tekrarlayan tonsillit öyküsü & $21(\% 17,2)$ \\
\hline Apendektomi öyküsü & $4(\% 3,3)$ \\
\hline \multicolumn{2}{|l|}{ Laboratuvar Parametreleri } \\
\hline - $\quad B K\left(10^{3} / \mathrm{uL}\right)$ & $7625 \pm 2043^{*}$ \\
\hline - $\quad \mathrm{Hb}(\mathrm{g} / \mathrm{dL})$ & $12,6 \pm 1,2^{*}$ \\
\hline - $\quad$ Plt $\left(10^{3} / u L\right)$ & $320,2 \pm 78,9^{*}$ \\
\hline - $\quad$ CRP $(\mathrm{mg} / \mathrm{L})$ & $0,9(0,4-3,7)$ \\
\hline - $\quad \mathrm{ESH}(\mathrm{mm} / \mathrm{sa})$ & $7(3-14)$ \\
\hline - $\quad \operatorname{ALT}(\mathrm{U} / \mathrm{L})$ & $18(13-25)$ \\
\hline - $\quad \mathrm{Cr}(\mathrm{mg} / \mathrm{dL})$ & $0,4(0,3-0,5)$ \\
\hline
\end{tabular}

Ortanca (25-75, persentiller)

*Ortalama \pm standart sapma

AAA: Ailesel Akdeniz ateşi, VA: vücut ağırlığı, BK: beyaz küre, Hb: hemoglobin, PIt: platelet sayıSı, CRP: C-reaktif protein, ESH: eritrosit sedimantasyon hızı,

ALT: alanin aminotransferaz, Cr: kreatinin 
Tablo 2. MEFV gen mutasyonlarının dağılımı

\begin{tabular}{ll}
\hline M694V/R202Q & $26(\% 21,3)$ \\
\hline R202Q/R202Q & $\mathbf{2 0}(\% 16,4)$ \\
R202Q & $\mathbf{2 0}(\% 16,4)$ \\
M694V & $\mathbf{8}(\% 6,5)$ \\
M694V/M694V/R202Q/R202Q & $\mathbf{6}(\% 4,9)$ \\
M694V/M694V/R202Q & $\mathbf{5}(\% 4,1)$ \\
M694V/M680I/R202Q & $\mathbf{5}(\% 4,1)$ \\
V726A & $5(\% 4,1)$ \\
M694V/M694V & $4(\% 3,3)$ \\
M694V/R202Q/R202Q & $3(\% 2,5)$ \\
M694V/R202Q/E148Q & $2(\% 1,6)$ \\
A744S & $3(\% 2,5)$ \\
R761H & $2(\% 1,6)$ \\
M694V/M680I & $1(\% 0,8)$ \\
M694V/R761H & $1(\% 0,8)$ \\
M694V/V726A/R202Q & $1(\% 0,8)$ \\
M694V/A744S/R202Q & $1(\% 0,8)$ \\
M680I /A744S/E148Q & $1(\% 0,8)$ \\
M680I/R761H & $1(\% 0,8)$ \\
M680I & $1(\% 0,8)$ \\
M680I/V726A & $1(\% 0,8)$ \\
M680I/E148Q & $1(\% 0,8)$ \\
M680I/R202Q & $1(\% 0,8)$ \\
K695R & $1(\% 0,8)$ \\
A744S/E148Q & $1(\% 0,8)$ \\
V726A/R202Q & $1(\% 0,8)$ \\
\hline
\end{tabular}

homozigot değişikliğin ise sağlıklı grupta daha az (\%14,7 ye karşı \%2,7) olduğunu bildirmişlerdir. Sönmezgöz ve ark.'nın [20] 2019'da yayınlanan bir çalışmasında da R202Q'nun M694V mutasyonu ile birlikte en sık görülen MEFV gen değişikliği olduğunu ve bu genotipin göğüs ağrısı görülme riskini arttırdığını bildirmişlerdir. Sonuç olarak R202Q gen değişikliğinin hastalık yapıcı bir mutasyon olduğunu ileri sürmüşlerdir. Celep ve ark.'nın [7] Anadolu'nun kuzey bölgesinden bildirdiği benzer bir çalışmada da, AAA klinik tanısı ile takip ettikleri 379 çocuk hastada en sık saptanan MEFV gen değişikliğinin R202Q olduğunu rapor etmişlerdir $(\% 50,1)$. Mevcut çalışmamızın sonuçları da Ankara kriterleri ile AAA tanısı koyarak takip ettiğimiz ve atakları kolşisin tedavisi ile kontrol altına alınan R202Q gen değişimi olan çocuk hastalarımızın anlamlı klinik bulguları olduğunu göstermektedir. Ayrıca, hem homozigot hem de heterozigot R202Q değişikliğinin kliniğe benzer oranda yansıyan bulgulara neden olabileceği gösterilmiştir.

Hastalığın genotipik özelliklerindeki değişiklikler, çevresel etmenler ve epigenetik farklılıklarla birleştiğinde fenotipik özelliklerde çeşitliliğe yol açmaktadır [21]. Literatürde özellikle ekzon 10 mutasyonlarının erken yaşta şiddetli ataklar, ağır eklem şikâyetleri ve artmış amiloidoz riski ile ilişkilendirildiği gösterilmiştir [6-11]. Ekzon 2'deki R202Q ve E148Q gibi değişikliklerin de klinik bulgular üzerinde etkisi olduğu, fakat daha hafif hastalık seyrine yol açtığını bildiren birçok çalışma literatürde mevcuttur. Çomak ve ark. [22] bir çalışmasında, homozigot R202Q değişikliği bulunan çocuk hastalardaAAA kliniği görüldüğü, fakat belirtilerin daha geç yaşlarda başladığı ve hafif kliniğe sebep olduğu rapor edilmiştir. Yakın zamanda Milenkoviç ve ark. [23] bildirdiği diğer bir çalışmada da homozigot R202Q değişikliğinin, E148Q (ekzon-2) ve K695R (ekzon-10) gen değişikliklerine göre daha sık ateşli karın ağrısı ataklarına ve daha fazla halsizlik belirtilerine neden olduğu gösterilmiştir. Mevcut çalışmadan 
Tablo 3. MEFV gen analiz sonuçlarına göre oluşturulan grupların demografik, antropometrik, klinik ve laboratuvar verileri açısından kıyaslanması

\begin{tabular}{|c|c|c|c|c|c|}
\hline & $\begin{array}{l}\text { Grup 1 } \\
R 202 Q+/- \\
n=20\end{array}$ & $\begin{array}{l}\text { Grup } 2 \\
R 202 Q+/+ \\
n=20\end{array}$ & $\begin{array}{l}\text { Grup } 3 \\
\text { R202Q (+)/ } \\
\text { ekzon } 10 \text { (+) } \\
n=52\end{array}$ & $\begin{array}{l}\text { Grup } 4 \\
\text { Ekzon } 10(+) / \\
\operatorname{R202Q}(-) \\
n=30\end{array}$ & $\begin{array}{l}p \\
\text { değeri }\end{array}$ \\
\hline Cinsiyet (k/e) (n) & $10 / 10$ & $7 / 13$ & $28 / 24$ & $15 / 15$ & 0,56 \\
\hline $\begin{array}{l}\text { İlk atak yaşı (yıl) } \\
\text { Median (\%25-75) }\end{array}$ & $4(2-7,5)$ & $3,5(3-10)$ & $5(2,5-8)$ & $4,2(3-5,6)$ & 0,12 \\
\hline $\begin{array}{l}\text { Kolşisin başlama yaşı (yıl) } \\
\text { Median (\%25-75) }\end{array}$ & $5(3,5-11)$ & $6,5(4,3-11)$ & $6,6(3,5-10)$ & $5,5(4-9)$ & 0,22 \\
\hline $\begin{array}{l}\text { Tanıda gecikme süresi (ay) } \\
\text { Median (\%25-75) }\end{array}$ & $12(6-26)$ & $20(12-33)$ & $10(4-18)$ & $12(8-32)$ & 0,42 \\
\hline $\begin{array}{l}\text { VA persentil (\%) } \\
\text { Median (\%25-75) }\end{array}$ & $58(36-96)$ & $40(12,3-80)$ & $52(27-82)$ & $55(36-78)$ & 0,28 \\
\hline $\begin{array}{l}\text { Boy persentil (\%) } \\
\text { Median (\%25-75) }\end{array}$ & $85(55-99)$ & $65(24-85)$ & $72(36-89)$ & $72(35-88)$ & 0,27 \\
\hline $\begin{array}{l}\text { AAA aile öyküsü } \\
\text { [n (\%)] }\end{array}$ & $8(\% 40)$ & $4(\% 25)$ & $23(\% 44)$ & $14(\% 46)$ & 0,23 \\
\hline \multicolumn{6}{|l|}{ Atak belirtileri } \\
\hline - $\quad$ Ateş [n (\%)] & $20(\% 70)$ & $16(\% 80)$ & $46(\% 88)$ & $28(\% 93)$ & 0,15 \\
\hline - $\quad$ Karın ağrısı [n (\%)] & $13(\% 65)$ & $16(\% 80)$ & $40(\% 76)$ & $24(\% 80)$ & 0,14 \\
\hline - $\quad$ Artrit [n (\%)] & $5(\% 20)$ & $3(\% 15)$ & $9(\% 17)$ & $6(\% 25)$ & 0,67 \\
\hline - $\quad$ Artralji [n (\%)] & $9(\% 45)$ & $6(\% 30)$ & $21(\% 40)$ & $14(\% 47)$ & 0,91 \\
\hline - $\quad$ Göğüs ağrısı [n (\%)] & $2(\% 10)$ & $1(\% 5)$ & $1(\% 2)$ & $4(\% 13)$ & 0,21 \\
\hline $\begin{array}{l}\text { Atak arası kas-iskelet } \\
\text { şikâyetleri [n (\%)] }\end{array}$ & $7(\% 35)$ & $3(\% 15)$ & $14(\% 27)$ & $11(\% 36)$ & 0,77 \\
\hline $\begin{array}{l}\text { Tekrarlayan tonsillit öyküsü } \\
\text { [n (\%)] }\end{array}$ & $6(\% 30)$ & $4(\% 20)$ & $7(\% 13)$ & $4(\% 13)$ & 0,10 \\
\hline Apendektomi öyküsü [n (\%)] & $1(\% 5)$ & 0 & $3(\% 5)$ & 0 & 0,78 \\
\hline $\begin{array}{l}\text { AAA ciddiyet skoru } \\
\text { Median }(\% 25-75)\end{array}$ & $6(4-7,3)$ & $5(4-6,4)$ & $6(5-7,2)$ & $6(5-6,5)$ & 0,62 \\
\hline $\begin{array}{l}\text { Kolşisin dozu (mg/gün) } \\
\text { Median (\%25-75) }\end{array}$ & $1,0(0,6-1,0)$ & $1,0(1,0-1,0)$ & $1,0(0,5-1,0)$ & $1,0(1,0-1,0)$ & 0,44 \\
\hline \multicolumn{6}{|l|}{ Laboratuvar } \\
\hline - $\quad$ BK [Mean $\pm S D]$ & $7506 \pm 1510$ & $6050 \pm 1397$ & $7713 \pm 2406$ & $7470 \pm 1760$ & 0,50 \\
\hline - $\quad \mathrm{Hb}[$ Mean $\pm S D]$ & $12,78 \pm 0,95$ & $12,62 \pm 1,62$ & $12,6 \pm 1,32$ & $12,7 \pm 1,0$ & 0,41 \\
\hline - $\quad$ PIt [Mean $\pm S D]$ & $313,2 \pm 77,1$ & $335 \pm 44,8$ & $321,2 \pm 89,2$ & $310,7 \pm 72,9$ & 0,42 \\
\hline - $\quad$ NLR Median (\%25-75) & $1,5(0,85-1,87)$ & $1,1(0,75-1,6)$ & $1,2(0,9-1,6)$ & $1,2(0,7-1,4)$ & 0,38 \\
\hline - $\quad$ CRP Median (\%25-75) & $0,4(0,3-0,9)^{\mathrm{a}}$ & $0,55(0,2-1,8)^{a}$ & $1,55(0,62-4,57)^{b}$ & $0,7(0,3-3,1)^{\mathrm{a}}$ & 0,03 \\
\hline - $\quad$ ESH Median (\%25-75) & $4(2-12,75)$ & $8,5(8-11,25)$ & $7(4-17,75)$ & $5(3-10)$ & 0,23 \\
\hline - $\quad$ ALT Median (\%25-75) & $17(13,25-25)$ & $17,5(12,2-34,75)$ & $18(13-25)$ & $20(13-24)$ & 0,99 \\
\hline - $\quad$ Cr Median (\%25-75) & $0,4(0,3-0,5)$ & $0,46(0,43-0,75)$ & $0,4(0,33-0,5)$ & $0,44(0,34-0,54)$ & 0,36 \\
\hline
\end{tabular}

AAA: Ailesel Akdeniz ateşi, VA: vücut ağırlığı, BK: beyaz küre, Hb: hemoglobin,

PIt: platelet sayıSı, NLR: nötrofil/lenfosit oranı, CRP: C-reaktif protein,

ESH: eritrosit sedimantasyon hızı, ALT: alanin aminotransferaz, Cr: kreatinin

"a" ve "b" grupları arasında istatistiksel anlamlı fark vardır. 
elde ettiğimiz veriler bize $\mathrm{R} 202 \mathrm{Q}$ değişikliğini en az bir allelinde bile taşıyan hastaların, her iki allelinde bulunduran ve ekzon-10 mutasyonu olan hastalara benzer atak ve atak arası belirtilerine ve hastalık ciddiyet skorlarına sahip olduğunu göstermektedir. Literatür verilerinin aksine çalışmamızın verileri, bu hasta grubunun ekzon-10 mutasyonu taşıyan grup ile benzer hastalık başlangıç yaşına sahip olduğunu göstermektedir.

Hastalığın kliniğinde görülen ateşli poliserozit ataklarının buzdağının görünen yüzü olduğu, bunun dışında ataklar arası dönemde de süreğen bir inflamasyonun olduğu son yıllardaki çalışmalarda öne sürülmüştür [24, 25]. Tedaviye direnç, ataklar arası yüksek akut faz yanıtları gibi risk faktörleri sıklıkla M694V homozigot mutasyonlu hastalarda süreğen inflamasyon ile ilişkilendirilmektedir [24]. Bununla birlikte Balkarlı ve ark. [26], R202Q gen değişimi bulunan hastalarında artmış metabolik sendrom riski saptamışlar (atfedilmiş risk: 4,42 ) ve bu durumu süreğen inflamasyon ile ilişkilendirmişlerdir. Benzer şekilde, Fentoğlu ve ark. [27] çalışmasında da, R202Q nun M694V mutasyonu ile birlikte oluşturduğu süreğen inflamasyonun, kronik periodontit riskinde istatistiksel anlamlı bir artışa neden olduğu öne sürülmüştür. Bu süreğen inflamasyonun daha geniş ve çok merkezli hasta popülasyonunda değerlendirilmesi, R202Q mutasyonun klinik üzerine etkisi ile ilgili kapsamlı bilgi edinmemizi sağlayacaktır.

Sonuç olarak, R202Q gen değişikliğine sahip hastalarda da ekzon 10 mutasyonlu hastalar gibi tipik AAA klinik bulguları gözlenebilmektedir. Ailesel Akdeniz ateşi, genotipik ve fenotipik özelliklerinin birlikte değerlendirilmesi gereken bir hastalıktır. Genetik odaklı çalışmalarda elde edilen farklı sonuçlar çevresel etkenler ve epigenetik faktörlerin de etkin değişkenler olabileceğini düşündürmektedir. Konu ile ilgili daha kapsamlı çalışmalar, klinik çeşitliliği anlamamızda fayda sağlayacaktır.

Çıkar ilişkisi: Yazarlar arasında çıkar ilişkisi olmadığını beyan eder.

\section{Kaynaklar}

1. Özen S. Update on the epidemiology and disease outcome of familial Mediterranean fever. Best Pract Res Clin Rheumatol 2018;32:254-260. https://doi. org/10.1016/j.berh.2018.09.003
2. Özen S, Batu ED, Demir S. Familial Mediterranean Fever: recent developments in pathogenesis and new recommendations for management. Front Immunol 2017;8:253. https://doi.org/10.3389/fimmu.2017.00253

3. Ancient missense mutations in a new member of the RoRet gene family are likely to cause familial Mediterranean fever. The International FMF Consortium. Cell 1997;90:797-807. https://doi. org/10.1016/s0092-8674(00)80539-5

4. French FMF Consortium. A candidate gene for familial Mediterranean fever. Nat Genet 1997;17:25-31. https:// doi.org/10.1038/ng0997-25

5. Infevers genetical database. Available at: https://https:// infevers.umai-montpellier.fr/web/search.php?n=1. Accessed Jan 14, 2021

6. Yaşar Bilge Ş, Sarı İ, Solmaz D, et al. The distribution of MEFV mutations in Turkish FMF patients: multicenter study representing results of Anatolia. Turk J Med Sci 2019;49:472-477. https://doi.org/10.3906/sag-1809100"10.3906/sag-1809-100

7. Celep G, Durmaz ZH, Erdogan Y, Akpinar S, Kaya SA, Guckan R. The Spectrum of MEFV gene mutations and genotypes in the Middle Northern Region of Turkey. Eurasian J Med 2019;51:252-256. https://doi. org/10.5152/eurasianjmed.2019.18396

8. Akin H, Onay H, Turker E, Cogulu O, Ozkinay F. MEFV mutations in patients with familial Mediterranean fever from the Aegean region of Turkey. Mol Biol Rep 2010;37:93-98. https://doi.org/10.1007/s11033-0099543-1

9. Akpolat T, Özkaya O, Özen S. Homozygous M694V as a risk factor for amyloidosis in Turkish FMF patients. Gene 2012;492:285-289. https://doi.org/10.1016/j. gene.2011.10.012

10. Lidar $\mathrm{M}$, Yonath $\mathrm{H}$, Shechter $\mathrm{N}$, et al. Incomplete response to colchicine in M694V homozygote FMF patients. Autoimmun Rev 2012;12:72-76. https://doi. org/10.1016/j.autrev.2012.07.025

11. Akpolat T, Yilmaz E, Ozen S, Akpolat I, Danaci M, Kandemir B. M680I(Arm2)/M694V(Med) mutations in a patient with familial Mediterranean fever and polyarteritis nodosa. Nephrol Dial Transplant 1998;13:2633-2635. https://doi.org/10.1093/ndt/13.10.2633

12. Bernot A, da Silva C, Petit JL, et al. Non-founder mutations in the MEFV gene establish this gene as the cause of familial Mediterranean fever (FMF). Hum Mol Genet 1998;7:1317-1325. https://doi.org/10.1093/ $\mathrm{hmg} / 7.8 .1317$

13. Ritis K, Giaglis S, Spathari N, et al. Non-isotopic RNase cleavage assay for mutation detection in MEFV, the gene responsible for familial Mediterranean fever, in a cohort of Greek patients. Ann Rheum Dis 2004:63:438443. https://doi.org/10.1136/ard.2003.009258

14. Ozturk A, Ozcakar B, Ekim M, Akar N. Is MEFV gene Arg202Gln (605 G>A) A disease-causing mutation? Turk J Med Sci 2008;38:205-208. 
15. Yigit S, Karakus N, Tasliyurt T, Uzun Kaya S, Bozkurt N, Kisacik B. Significance of MEFV gene R202Q polymorphismin Turkish familial Mediterranean fever patients. Gene 2012;506:43-45. https://doi. org/10.1016/j.gene.2012.06.074

16. Infevers genetical database. Available at: https://https:// infevers.umai-montpellier.fr/web/detail_mutation.php. Accessed Jan 14, 2021

17. Yalçinkaya F, Ozen S, Ozçakar ZB, et al. A new set of criteria for the diagnosis of familial Mediterranean fever in childhood. Rheumatology (Oxford) 2009;48:395398. https://doi.org/10.1093/rheumatology/ken509

18. Nevzi $O$, Günöz $H$, Furman $A$, et al. Türk çocuklarında vücut ağırlığı, boy uzunluğu, baş çevresi ve vücut kitle indeksi referans değerleri. Çocuk Sağlığı ve Hastalıkları Dergisi 2008;51:1-14.

19. Pras E, Livneh A, Jr Balow JE, et al. Clinical differences between North African and Iraqi Jews with familial Mediterranean fever. Am J Med Genet 1998;13;75:216219.https://doi.org/10.1002/(sici)10968628(19980113)75:2<216::aid-jmg20>3.0.co;2-r

20. Sönmezgöz E, Özer S, Gül A, et al. Clinical and demographic evaluation according to MEFV genes in patients with familial mediterranean fever. Biochem Genet 2019;57:289-300. https://doi.org/10.1007/ s10528-018-9889-y

21. Kirectepe AK, Kasapcopur O, Arisoy N, et al. Analysis of MEFV exon methylation and expression patterns in familial Mediterranean fever. BMC Med Genet 2011;12:105. https://doi.org/10.1186/1471-2350-12105

22. Comak E, Akman S, Koyun M, et al. Clinical evaluation of R202Q alteration of MEFV genes in Turkish children. Clin Rheumatol 2014;33:1765-1771. https://doi. org/10.1007/s10067-014-2602-6

23. Milenković J, Vojinović J, Debeljak M, et al. Distribution of MEFV gene mutations and $R 202 Q$ polymorphism in the Serbian population and their influence on oxidative stress and clinical manifestations of inflammation. Pediatr Rheumatol Online J 2016;14:39. https://doi. org/10.1186/s12969-016-0097-1

24. Bayram MT, Çankaya T, Bora E, et al. Risk factors for subclinical inflammation in children with familial Mediterranean fever. Rheumatol Int 2015;35:13931398. https://doi.org/10.1007/s00296-015-3227-z

25. Özer S, Yılmaz R, Sönmezgöz E, et al. Simple markers for subclinical inflammation in patients with familial Mediterranean fever. Med Sci Monit 2015;21:298-303. https://doi.org/10.12659/MSM.892289

26. Balkarli A, Akyol M, Tepeli E, Elmas L, Cobankara V. MEFV gene variation $R 202 Q$ is associated with metabolic syndrome. Eur Rev Med Pharmacol Sci 2016;20:3255-3261.
27. Fentoğlu Ö, Dinç G, Bağcı Ö, et al. R202Q/M694V as novel MEFV gene mutations in chronic periodontitis and familial Mediterranean fever. J Periodontal Res 2017;52:994-1003. https://doi.org/10.1111/jre.12467

Etik kurul onayı: Dokuz Eylül Üniversitesi Girişimsel Olmayan Etik Kurulu'ndan 15/02/2021 tarihli ve $2021 / 05-27$ onay numaralı etik kurul onayı alınmıştır.

\section{Yazarların makaleye olan katkıları}

S.T., C.Y. ve E.U. çalışmanın ana fikrini ve hipotezini kurgulamışlardır. S.T. teoriyi geliştirmiş, gereç ve yöntem bölümünü düzenlemiştir. Sonuçlar kısmındaki verilerin değerlendirmesini E.U., S.T. ve H.A.D. yapmışlardır. Makalenin tartışma bölümü S.T. tarafından yazıımış, E.U. gözden geçirip gerekli düzeltmeleri yapmış ve onaylamıştır. Ayrıca tüm yazarlar çalışmanın tamamını tartışmış ve son halini onaylamıştır. 